\title{
The millstone trade from the most exploited Italian volcanic areas: an overview from the phoenicians to the roman period
}

\author{
Patrizia Santi*,1, Timmy Gambin ${ }^{2}$, Alberto Renzulli ${ }^{1}$ \\ (1) Dipartimento di Scienze Pure e Applicate, Campus Scientifico “Enrico Mattei”, Università degli Studi di Urbino Carlo \\ Bo, Urbino, Italy \\ (2) Department of Classics and Archaeology, University of Malta, Malta
}

Article history: received March 1, 2021; accepted September 30, 2021

\begin{abstract}
Lavas were widely used in antiquity to produce millstones. This is mainly due to their superior properties for grinding cereals and availability when compared with other rock-types. In the past four decades, several studies have been published about lava millstones discovered in subaerial and submarine archaeological sites of the Central-Western Mediterranean. Although the morphological evidence of old quarries is rarely present, all these studies were aimed at recognizing provenance and manufacturing areas of the volcanic raw material. Typologies of grinding tools coexisted in different periods, even if some technological developments marked transitions between cultures. The main chronology is: Archaic saddle quern, Greek hopper-rubber (Olynthian), small to medium size rotary device (Morgantina type) and large hourglass rotary millstone (Pompeian style). Potential volcanic sources are widespread throughout the entire Mediterranean region, but two main Italian quarrying areas of volcanic rocks for the manufacture of millstones from the Phoenician to the Roman period were pointed out. These are the Latium-Umbria border in Central Italy, and Sicily (Eastern Sicily and Sicilian Channel) in Southern Italy. In detail, analysis of the lava lithotypes shows that grinding tools were mainly constructed of: (i) a leucite phonolite of the so called "Orvieto quarries" between the localities of Sugano and Buonviaggio in the Roman Volcanic Province (High$\mathrm{K}$ alkaline series); (ii) hawaiites and mugearites (Na-alkaline series) from Etna volcano; (iii) basalts (Tholeiitic/Transitional series) of the Hyblaean Mountains and (iv) basalts (Na-alkaline series) from Pantelleria Island (Sicilian Channel). Although some lava millstones from other volcanic regions are recorded, the above four Italian volcanic rock types represent the most exploited in antiquity. A comparison between volcanic millstones and outcropping lavas already exists, from literature data, through thin section modal mineralogy and conventional igneous petrology (i.e., TAS classification, magmatic affinities, and major-trace elements signature). Therefore, on this basis we propose a set of discriminating geochemical parameters (major-trace elements and element ratios diagrams) useful for a quick assessment tool to possibly evaluate one of these four exploited volcanic areas of Italy matching millstones. A sketch of volcanic millstone trade networks and commercial routes in antiquity throughout the Central-Western Mediterranean has been also reported and overviewed on the basis of the literature data.
\end{abstract}

Keywords: Millstones; Lavas; Quarries; Roman Magmatic Province; Etna; Hyblaean Mountains; Pantelleria Island; Central-Western Mediterranean. 


\section{Patrizia Santi et al.}

\section{Introduction}

Lavas were one of the most sought-after materials to produce querns and millstones for the grinding of cereals in ancient times [Curtis, 2001; Hockensmith ,2009; Williams and Peacock, 2011; Alonso and Frankel, 2017]. Either mafic or felsic, lava lithologies generally ensured good wear resistance and grinding capacity also when compared to sandstones and quartzites that in fact resulted in a more sporadic use. Lava flows with a welldeveloped vesiculation were preferentially quarried because of the good workability and a relatively lower density that facilitated the transport of finished products. However, the accessibility of lava outcrops, the reserves (availability and real chance of exploitation), the processing and transport methods induced to choose different types of rock materials. Finally, it is necessary to take into account the limitations of access to certain regions dictated by the existing political, economic and/or military conditions [Griffiths 2000].

Several archaeometric studies of numerous millstones from a long chronological period and from a variety of archaeological sites in the Central-Western Mediterranean, including shipwrecks, have been published in the last four decades [Peacock, 1980, 1986, 1989; Ferla et al., 1984; Williams-Thorpe, 1988; Williams-Thorpe and Thorpe, 1988, 1990, 1991, 1993; Renzulli et al., 2002, 2019; Santi et al., 2004, 2013, 2015, 2020; Antonelli et al., 2004, 2010, 2014; Santi and Renzulli, 2006; Gluhak and Schwall, 2015; Di Bella et al., 2018 ]. These studies allowed to unravel the millstone typologies preferentially used through time and to establish the exploited lava lithotypes, also leading to a better understanding of the trade routes throughout the Mediterranean. There is a useful petrographic and geochemical database for materials employed in the production of lava millstones from the Archaic period to the Roman Empire.

The technological evolution of the grinding stones has been linked, starting from the Archaic period, to an increasing demand for flour, necessary to meet the bread-making needs of the growing population in the Mediterranean area. The demographic increase stimulated the development of more and more efficient grinding devices. The technological evolution was as follows (Figure 1): Archaic saddle querns, Greek hopper-rubbers (Olynthian) and small or medium sized rotary devices (Morgantina type) and large Roman hourglass rotary millstones (Pompeian style).

Although reserves of lavas are widespread throughout the entire Mediterranean region, decades of researches on provenance of lava millstones point to quarries (or provenance areas if quarries were not found) located in two main Italian districts: the Latium-Umbria border and Sicily (Eastern Sicily and Sicilian Channel) in Central and Southern Italy, respectively [Peacock, 1986, 1989; Williams-Thorpe, 1988; Williams-Thorpe and Thorpe, 1993; Renzulli et al., 2002, 2019; Santi et al., 2004, 2013, 2015, 2020; Antonelli et al., 2010]. In particular, the literature well established that the most exploited lavas to manufacture millstones in antiquity were: (i) a leucite phonolite from the Vulsini Volcanic District in Central Italy, (ii) hawaiites and mugearites from Etna, and basalts from (iii) Hyblaean Mountains and (iv) Pantelleria (Sicily and Sicilian Channel). In response to these emerging patterns, here we present an efficient assessment tool to locate lava millstone source areas in the form of geochemical diagrams for each of the four aforementioned volcanic lithotypes. These are based on the data sets compatible, mineralogically and petrographically, with most of the lava millstone lithotypes found in Central Western Mediterranean: basaltic rocks of the Na-alkaline and Tholeiitic-Transitional series and leucite phonolites of the high-K alkaline series. Plotting lava millstone geochemical parameters in the proposed diagrams, has to be however complemented by verifying compatibility through thin section modal mineralogy, Total Alkali-Silica (TAS) classification and petrogenetic signature (i.e., magmatic series). Besides the most exploited areas of Latium-Umbria border, Eastern Sicily and Sicilian Channel, additional minor source areas for volcanic millstone production in antiquity were however recognized in some trachyte lavas from the Euganean Hills (Venetian Magmatic Province [Renzulli et al., 2002; Santi and Renzulli, 2006; Antonelli et al., 2004], a dacite to rhyolite welded ignimbrite from the Mulargia area (Sardinia) [Antonelli et al., 2014], and lavas from Vesuvius, Aeolian Archipelago and Ustica Island [Williams-Thorpe, 1988; Williams-Thorpe and Thorpe, 1993; Renzulli et al., 2002, 2019; Antonelli et al., 2010; Santi et al., 2013, 2020; Di Bella et al., 2018]. Although lava millstone provenance from volcanic areas in the Eastern Mediterranean (Greece, Lebanon, Syria, Israel and Jordan) is beyond the scope of the present work, a brief discussion on these potential volcanic rock sources will be also given. 


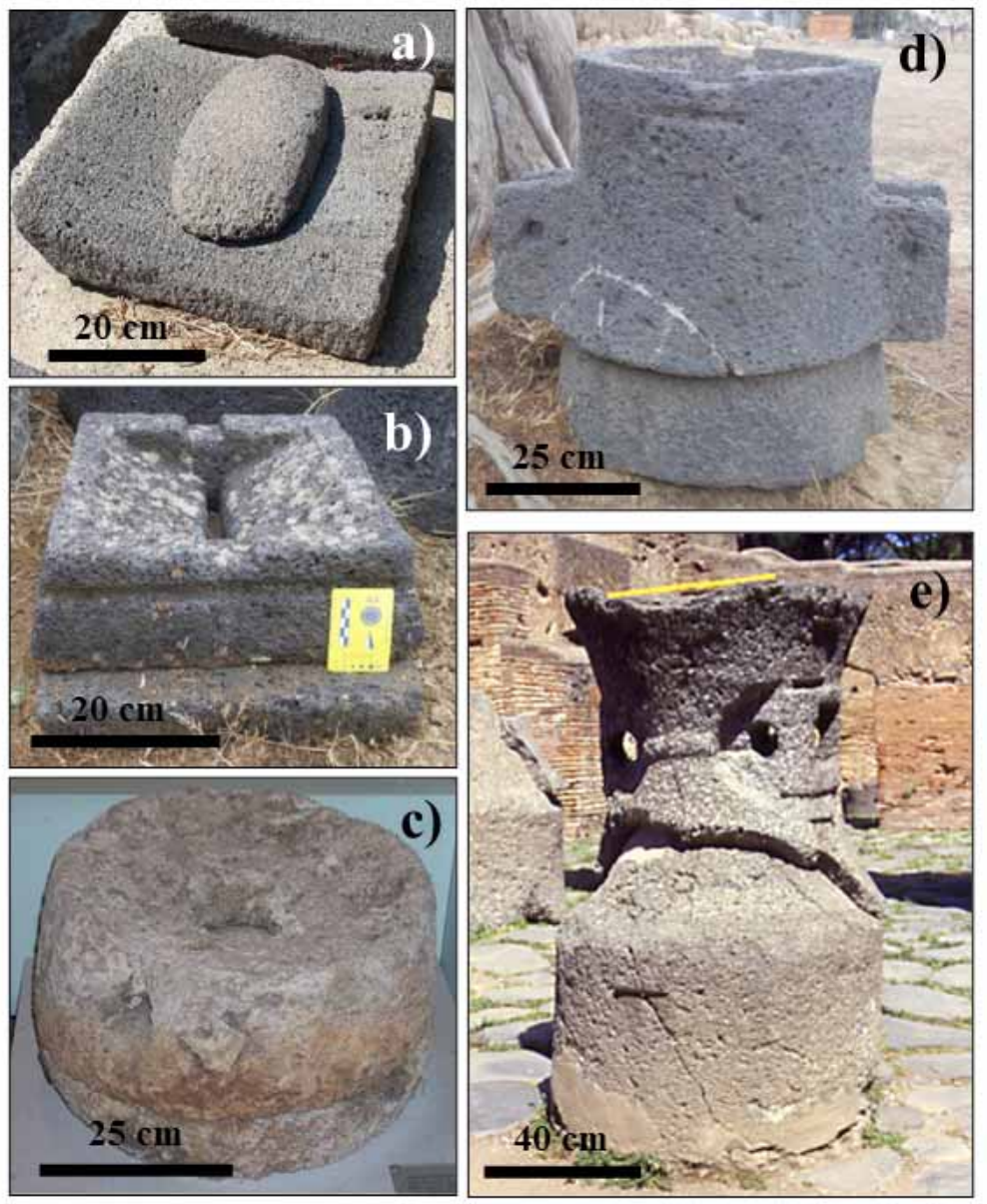

Figure 1. Different millstones type used in antiquity: a) Saddle quern (Lipari Archaeological Museum, Aeolian Islands); b) Hopper-rubber millstone (Morgantina archaeological site, Sicily); c) Small rotary hand-mill (Lipari Museum Archaeological, Aeolian Islands); d) Morgantina type rotary millstone (Morgantina archaeological site, Sicily); e) Pompeian type millstone (Ostia Antica archaeological site, Rome).

\section{Evolution of the grinding techniques}

Millstones, together with the wheel (in Europe from 3000 BC), represent the first mechanical tools of widespread domestic use [Chartrain, 2015]. The utilisation of millstones in ancient times is usually connected to the grinding of cereals, although they were also employed for the processing of various fruits and olives [Moritz, 1958]. The appearance of the most ancient grinding techniques occurred alongside increased demand for cereals which needed be transformed into flour for consumption [Santi, 2020]. The oldest millstones date back to the Late Paleolithic [Elliott et al., 1986] and are referred to as saddle querns mainly due to the shape acquired by the lower part which is re-shaped by the grinding process [Moritz, 1958]. Saddle querns were in use simultaneously in numerous Mediterranean cultures including that of ancient Egypt [Moritz, 1958]. In essence, flour was produced by crushing the grains manually between two rock elements (Fig. 2a). Consisting of two parts, these millstones have undergone a change in their shape and size over time [Curtis, 2001]: the base became wider and flatter, while the upper mobile part, elliptical in shape, became thicker whilst developing two lateral grips in order to make grinding more effective. After thousands of years of exclusive use of saddle querns, a series of new devices for mills appeared and developed in the Mediterranean during the second half of the first millenium BC [Alonso and Frankel, 2017, and references therein].

Starting from the 5th century BC [White, 1963] the use of rectangular hopper-rubbers, also known as Olynthian type, spread widely throughout the Mediterranean [Williams-Thorpe and Thorpe, 1993; Frankel, 2003]. Defined by 


\section{Patrizia Santi et al.}

Cato as Molae Trusatiles [De Agri Cultura dating to ca. 160 BC; Moritz, 1958], these too consisted of two parts, a flat base on which a smaller stone (hopper to load the cereal) was placed, with a slit in the central part. The grinding took place through the oscillation of a lever fixed on the hopper (Figure 2b). Although their origin is still debated, since they may represent a technological offshoot of saddle querns, the most credible hypothesis is a Greek and/or Anatolian origin [Frankel, 2003; Curtis, 2001]. The use of hopper millstones represents a significant development in the production of flour as it evolves from the domestic use of saddle millstones to a more mechanized and productive system. This is also historically documented by the decoration of the Homeric Cup or Megarian Bowl found in Thebes (4th-3rd century BC) [Rostovtzeff, 1937] where hopper millstones are represented within a scene of flour production in a commercial center context (Figure 3).

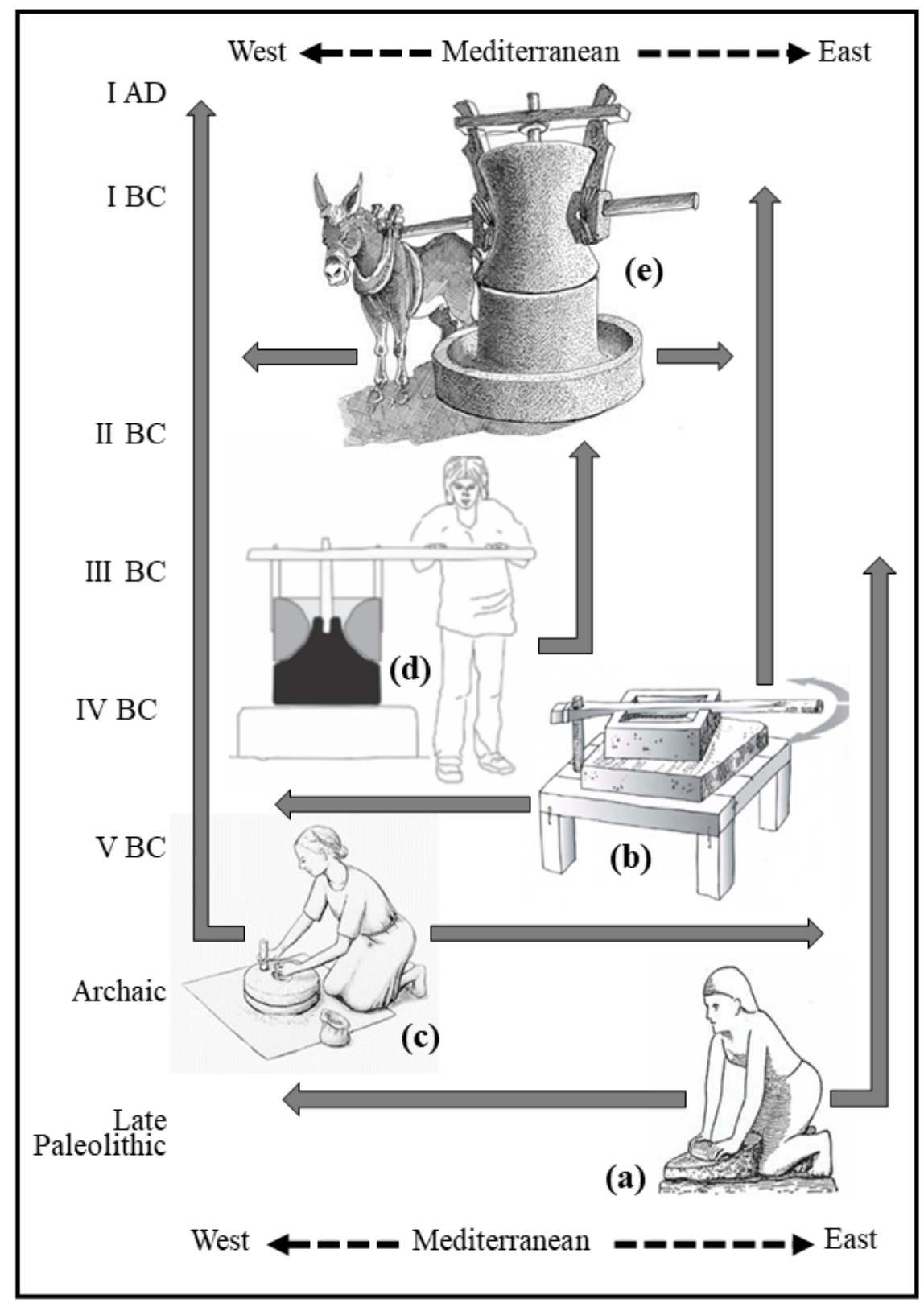

Figure 2. Evolutionary sketch of chronological and areal distribution of the grinding techniques in antiquity [Santi, 2020 modified]. a) Saddle quern; b) Hopper-rubber millstone; c) Small rotary hand-mill; d) Morgantina type rotary millstone; e) Pompeian type millstone. The grey arrows roughly indicate the time interval of use (vertical) starting from the millstone images located according to the inferred area where the grinding device was invented in the Mediterranean. 


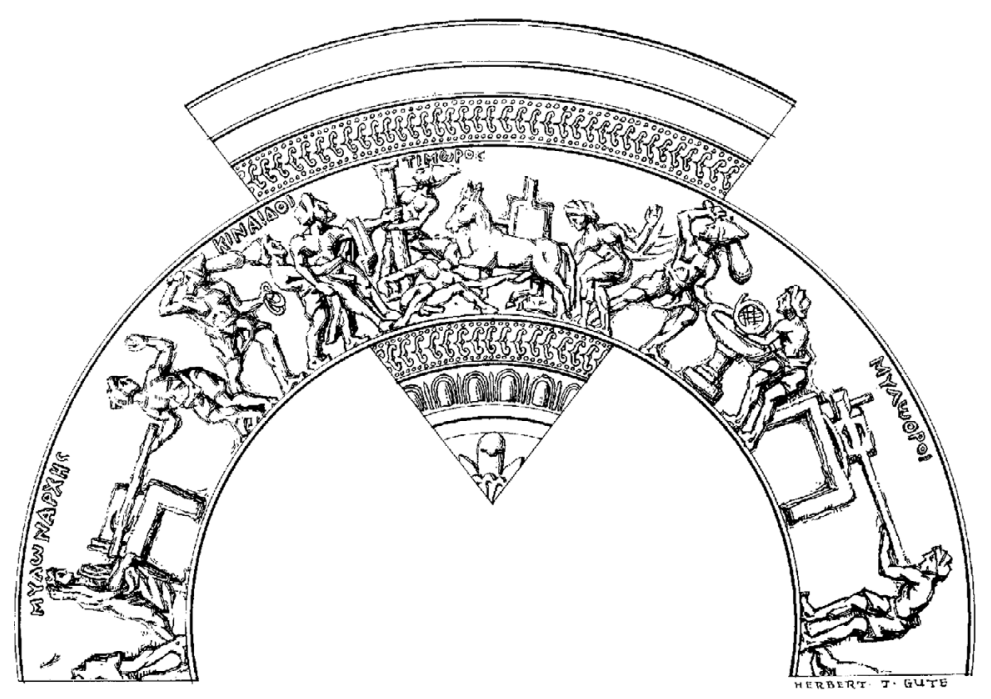

Figure 3. Graphic reproduction of the Megarian Blow discovered at Tebe (Egypt) and now held in the Museum of Louvre [Rostovtzeff, 1937].

Since the 6th century BC, simple rotary millstones that are Spanish in origin, begin to be widely used. Cato, writing in the second century BC, defines them as Molae Ispaniensis [Cato, De Agri Cultura; Childe, 1943]. Nevertheless, according to Chartrain [2015] it could be reasonably assumed the existence of simultaneous centers of diffusion and a polygenesis of the invention of rotary millstones. These small rotary hand-mills consisted of a fixed base with a slightly convex shape and a slightly concave rotating upper part. The latter had a hole in the center to feed the cereals into the mechanism (Figure 2c). The rotation was performed through a wooden handle inserted in the upper part. Although still a manual process, this grinding technique proved to be very popular as it guaranteed greater efficiency in the production of flour. Produced in varying sizes [Py, 1992], the most widespread average diameter is ca. $34 \mathrm{~cm}$ [Williams-Thorpe, 1988]. The smaller variants became tools for daily use in domestic contexts and were also used on ships for the production of meals by the crew and passengers. This is attested by the numerous discoveries of such objects on shipwrecks from the Greek and Roman periods [Williams-Thorpe and Thorpe, 1990]. These tools were also widely transported and utilised by the Roman legions during the military campaigns in Northern Europe [Junkelmann, 1997].

In the meantime, in numerous Phoenician-Punic sites such as Motya, Morgantina and Carthage, a new type of manual rotary mill appears [Wefers, 2011]. This consists of a fixed base (meta) and an upper part (catillus) characterized by two attachments (holes diametrically opposite) for the insertion of poles useful for its manual rotation (Figure 2d). These millstones are known as the Morgantina type [White, 1963], named for the archaeological site near Enna (Sicily) where they were found in large numbers. This typology has an average height of approximately 65-70 cm and they reached their maximum diffusion in the 4th-3rd century BC [White, 1963]. The vast distribution of Morgantina type millstones can be linked to the period of peace that characterized Sicily under the reign of Hiero II of Syracuse, who favored the procurement of materials from the Catania plain [Sjöqvist, 1960; Bell, 2011] and also to the Lex Ieronica [270 - $216 \mathrm{BC}$ ], which replaced the fixed tax contribution with a tithe. Taxes were thus commensurate with income and agricultural production. In turn, this prompted an increase in the cultivation of wheat, the construction of numerous public granaries and the need for grinding facilities. It should be emphasized that compared to the saddle querns, the efficiency of the hopper variants was sixfold - while for the Morgantina type rotary millstones efficiency was between six to twelve times greater [Holodňák, 2001]. This would account for their Mediterranean-wide distribution as attested by the cargo of a wreck from the 4th century BC discovered off the island of Mallorca (Spain) where no less than 38 hopper millstones, 16 catilli and 22 metae of Morgantina type millstones have been recorded [Williams-Thorpe and Thorpe, 1990]. The Morgantina type millstone can be considered, for all intents and purposes, as the prototype from which the most imposing hourglass millstones known as the Pompeian (Figure 2e) type developed. With an average height of ca. $150 \mathrm{~cm}$, this new millstone type represented a real revolution in the technique of grinding, passing from hand-operated rotary tools to grinders 


\section{Patrizia Santi et al.}

powered by animals [White, 1963]. Writing in the 1st century BC and citing Varro, Pliny the Elder [Naturalis Historiae; 77-78 AD] defines them as Molae Asinarie or Molae Versatiles and indicates the area of Volsinii (now Orvieto if considering Volsinii Veteres or Bolsena if considering Volsinii Novi) as the place where they were invented and produced. These hourglass millstones consist of a fully truncated conical part (meta), fixed to a base and an upper part that resembles a hollow hourglass (catillus). The latter constituted the reversible part (Molae Versatiles) in order to extend usage for as long as possible. Large-scale distribution of this typology begins in the 2nd-1st centuries BC [Mayesche, 1988; Peacock, 1989; Curtis, 2001; McCallum, 2010]. This happens in parallel with the development of public structures dedicated to grinding and for the production of bread as found in places such as Ostia Antica, Herculaneum and Pompeii.

During the Imperial period, Pompeian type millstones spread throughout the Mediterranean through a welldefined commercial network [Antonelli et al., 2001; Renzulli et al., 2002; Santi et al., 2004; Antonelli and Lazzarini, 2010]. Once again, this is attested by the numerous millstones discovered in many Roman wrecks dating mainly to the 2nd century BC to the 3rd century AD [Parker, 1992; Di Bella et al., 2016].

Given the high number of finds identified, it is possible to illustrate the technological evolution of grinding in time sequence (Fig. 2) roughly highlighting the geographical distribution (East to West Mediterranean). The simultaneous use of different grinding techniques also meets the varying needs for the production of flour through time and also testify that the invention of some new millstone device did not sharply eliminate usage of older grinding tools.

\section{Lava millstones in the Central-Western Mediterranean and volcanic source areas}

This chapter provides an overview of available literature on millstones made from the most exploited Italian volcanic regions. It encompasses subaerial archaeological sites of the Central-Western Mediterranean, as well as millstone cargoes from shipwrecks, and examines a broad chronological period from the Archaic to the Roman Period. The main methodological approach used in the studies of lava millstones provenance is to compare the petrographic and geochemical properties of manufacts against those of the volcanic areas where the materials may have been sourced to assess links between the two. It is worth to be noted that the geomorphological evidence of old quarries has been often erased by time (erosion and/or anthropization). The Total Alkali Silica (TAS) classification diagram of volcanic rocks [Le Bas et al., 1986] and the assessment of a specific magma series (Tholeiitic/Transitional, Calcalkaline, Na or K-alkaline, silica-undersaturated high-K alkaline) [Kuno 1968; Irvine and Baragar, 1971] represent the first step. Patterns of incompatible trace elements and rare earth elements (REEs) of lava millstone of basaltic compositions, normalized against primordial mantle and chondrites respectively [Sun and McDonough, 1989] are additional useful tools to shed light on the potential volcanic source areas, at least for not differentiated (mafic) lithotypes. This is because distinct trace element patterns of basaltic rocks are closely associated to different geodynamic settings: subduction-related oceanic arc or active continental margin volcanoes, middle oceanic ridge basalts (MORB), oceanic intraplate basalts (OIB) or continental flood basalts (CFB) environments [Rollinson, 1993; Winter, 2010]. TAS classification, magma series and major trace elements abundances therefore allow the early potential matching between lava millstones and volcanic source areas from subduction-related vs. anorogenic OIB magmatic regions [Lustrino and Wilson, 2007] for the Central-Western Mediterranean volcanism. As a volcano or a volcanic area of provenance was established, a millstone trade network can be thus outlined for a specific time interval, this latter being mainly established from the millstone device (cf. chapter 2 and Figure 2).

Although Italian volcanoes (active, dormant, or extinct) represent the best candidates for deducing the provenance of lava millstones [Santi and Renzulli, 2006] it was deemed necessary to also conduct comparisons with potential volcanic rocks mainly in Greece (subduction related lavas) and the whole Eastern Mediterranean (OIB sources). In fact, in the Levant area, lavas widely used in the ancient lithic industry and for the manufacture of millstones, include outcrops in the Lake Tiberias region (Israel), the Golan Heights, the Jordan Plateau and Northern Syria (see 3.2).

The literature data emphasize four main areas of extraction and production of millstones in the Central Western Mediterranean: 1) the leucite phonolite lava from the quarries near Orvieto (between the localities of Sugano and 
Buonviaggio) in the Vulsini Volcanic District close to the Northern Latium-Umbria border (Roman Magmatic Province) [Peacock, 1980, 1986, 1989; Ferla et al., 1984; Lorenzoni et al., 1996, 2000; Daniele, 1997; Buffone et al., 1999, 2003; Oliva et al., 1999; Antonelli et al., 2001, 2005; Renzulli et al., 2002; Renzulli and Santi, 2005; Santi and Renzulli, 2006; Santi et al. 2004; Antonelli and Lazzarini 2010]; 2) hawaiites and mugearites from Etna volcano [Williams-Thorpe 1988; Renzulli et al., 2002; Santi and Renzulli, 2006; Antonelli and Lazzarini, 2010; Santi et al., 2013, 2015, 2020]; 3) Tholeiitic/Transitional basalts from Hyblaean Mountains [Renzulli et al., 2002; Santi et al., 2013, 2015, 2020] and 4) High-TiO ${ }_{2} \mathrm{Na}$-alkaline basalts from Pantelleria Island [Williams-Thorpe, 1988; WilliamsThorpe and Thorpe, 1990; Renzulli et al., 2019; Santi et al., 2020].

\subsection{Leucite phonolite from the "Orvieto quarries" (Vulsini Volcanic District, Roman Magmatic Province)}

According to the above literature, the leucite phonolite lava extracted from quarries near the city of Orvieto in the Vulsini Volcanic District [Nappi et al., 1995] represents a very widespread lithotype for grinding stones in the whole Central-Western Mediterranean mainly as hopper-rubbers and rotary Pompeian type millstones. Washington [1896], in his pioneer petrographic work on the Vulsini Volcanic District uses a straightforward thin section report to describe an outcrop of vescicular, leucite-phyric phonolite lava with "trachytic" groundmass, located about $3 \mathrm{~km}$

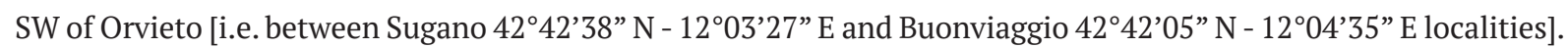
It is worth to note that no relationships exist with the Orvieto town which is built upon a pyroclastic cliff (an ignimbrite) and not a lava flow. Nearly a century later, Peacock [1980, 1986] was the first to indicate this volcanic rock as the most similar in composition and texture to the materials used to make the rotary millstones found in the sites of Pompeii and Ostia Antica, suggesting a possible single area of origin located in this part of Central Italy (the ancient Etruria). The old quarries between Sugano and Buonviaggio can be still recognizable for morphological features and the presence of some unfinished metae and catilli of rotary millstones were also detected [Peacock 1986]. This lava is unequivocally characterized using modal mineralogy and major-trace elements [Antonelli et al., 2001; Santi et al., 2004]. On a macroscopic scale it is leucite-phyric (phenocrysts up to $15 \mathrm{~mm}$ in size) with a grey to pale-grey colour. In thin section it is represented by a highly vesciculated porphyritic lava (PI=25-30 vol.\%) with euhedral leucite phenocrysts and a microcrystalline, pilotassitic groundmass mainly consisting of sanidine and leucite microlites with subordinate plagioclase and clinopyroxene. Phenocrysts and microphenocrysts of clinopyroxene, plagioclase and sanidine are also present. Accessory phases are represented by opaque minerals and apatite [Santi et al., 2004]. Geochemical features of this leucite phonolite lava from the "Orvieto quarries" $\left(\mathrm{K}_{2} \mathrm{O} / \mathrm{Na}_{2} \mathrm{O}\right.$ between 2.8 and 4.1) are unique with respect to all the other leucite phonolites from the Roman Volcanic Province (i.e., Vico and Sabatini Complexes and Vesuvius; Fig. 4a, b) [Santi et al. 2004 and reference therein]. In particular, it is characterized by the highest Sr (1823-2026 ppm), La (172-194 ppm), Th (150-178 ppm) and Ba (2165-2313 ppm) contents [Antonelli et al., 2001] ever reported from similar leucite phonolite lavas of the Roman Volcanic Province. Millstones made of this lava have been identified at various Etruscan-Celtic and Roman sites such as in Monte Bibele (Bologna), Cannetolo di Fontanellato (Parma), Colombarone, Sant’Angelo in Vado, Fossombrone, Suasa and Urbisaglia (Marche), Ostia Antica (Rome), Pompeii (Naples), Valle del Biferno (Molise), Monte Castellazzo di Poggioreale and Rocca di Entella (Sicily), Les Martys, Montagne Noire (France) and North Africa (Libya, Tunisia) [Peacock, 1980; Ferla et al., 1984; Williams-Thorpe, 1988; Williams-Thorpe and Thorpe, 1993; Daniele, 1997; Oliva et al., 1999; Antonelli et al., 2001, 2005; Renzulli et al., 2002; Buffone et al., 1999, 2003; Santi et al., 2004; Renzulli and Santi, 2005; Santi and Renzulli, 2006]. The discovery of an Etruscan-Celtic hopper-rubber millstone in the archaeological site of Monte Bibele, Tuscany-Emilia Romagna Apennines [Renzulli et al., 2002] provides evidence of the exploitation of the "Orvieto quarries" starting as early as the 4 th century BC. The vast diffusion of millstones made with this leucite phonolite lava is undoubtedly due to the good physical characteristics of this lithotype and also to the strategic position of the quarries with regards to the commercial distribution networks. In the context of connectivity, it is imperative to highlight that the areas of exploitation, between the localities of Sugano and Buonviaggio were located about $10 \mathrm{~km} \mathrm{W-NW}$ from the confluence of the Tiber and Paglia rivers. At this point, the river port of Pagliano [Morelli, 1957; Bruschetti, 2004] was an important crossroads for most of the trade in Central Italy between the first half of the 1st century BC and the first century AD [Morelli, 1957]. This river port represented the main trading hub along the Tiber river itself [Antonelli et al., 2001]. From here the millstones reached Rome and, 


\section{Patrizia Santi et al.}

more importantly, Ostia Antica, from where they could easily be transhipped for redistribution throughout the Mediterranean. In the Mill Building (bakery) of Ostia Antica [2nd century BC - 3rd century AD] some of best examples of Roman Pompeian hourglass rotary millstones have been identified. These were all manufactured with the leucite phonolite lava from the "Orvieto quarries". At Ostia Antica the entire wheat processing production cycle, from milling to making the dough, to baking and selling the bread (Panis Fiscalis Ostiensis) took place [Santi et al., 2004]. Well preserved hourglass millstones of leucite phonolite from the "Orvieto quarries" were also found at Pompeii (hence the name Pompeian) and account for the $60 \%$ of the total grinding stones in this archaeological site, the remaining 40\% originating from Vesuvius volcanic rocks and very few from Etna [Buffone et al., 1999, 2003].
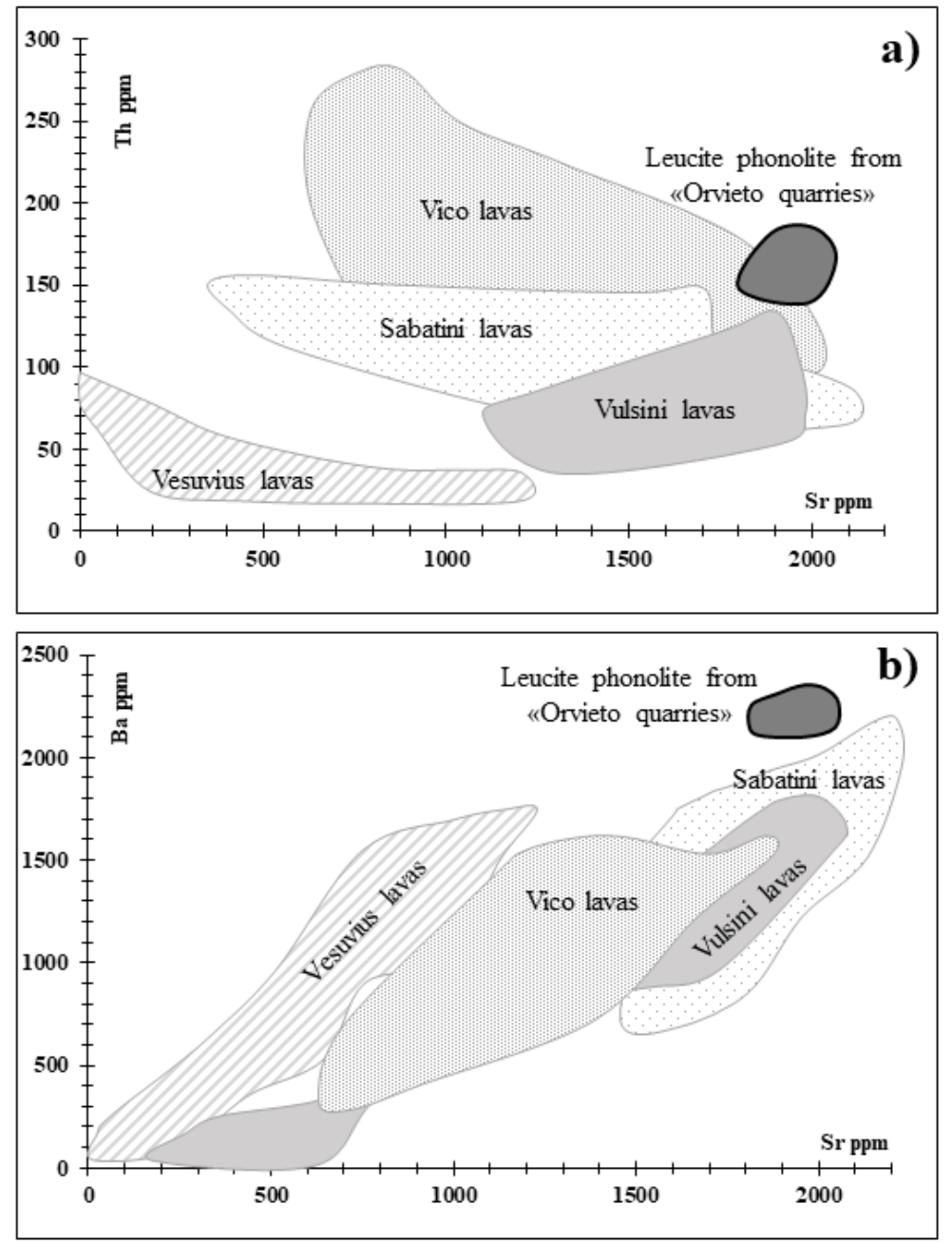

Figure 4. Th vs Sr (a) and Ba vs Sr (b) diagrams for the leucite phonolite lavas of the Roman Volcanic Province [Peccerillo, 2005] including those of the "Orvieto quarries" [Antonelli et al. 2001].

\subsection{Basaltic lavas from Eastern Sicily, Sicilian Channel and Levant region}

From the 7th century BC to the Roman period, the most exploited basaltic lavas for the production of millstones (saddle querns, hopper-rubber and rotary millstones found in the Central-Western Mediterranean) were those located in Eastern Sicily (Etna volcano and the Hyblaean Mountains) and the Sicilian Channel (Pantelleria Island) [WilliamsThorpe,1988; Williams-Thorpe and Thorpe, 1990, 1991]. Hawaiites and mugearites from Etna, alkaline basalts from Pantelleria and Tholeiitic-Transitional basalts from the Hyblaean Mountains were recognized as providing material for millstones found in numerous archaeological sites and shipwreck cargoes in the Central-Western Mediterranean, 
dated from the Archaic to the Roman period [Williams-Thorpe, 1988; Williams-Thorpe and Thorpe, 1990, 1991; Santi et al., 2013, 2015, 2020; Di Bella et al., 2016; Renzulli et al., 2019]. In particular, the presence of basaltic millstones coming from Etna, Hyblaean Mountains and Pantelleria was discovered, together or separately, in the sites of Motya and Entella [Daniele, 1997], Altamura [Lorenzoni et al., 1996, 2000], Fossombrone [Renzulli et al., 2002], Pompei [Buffone et al., 1999, 2003], Cyrenaica (Libya) [Antonelli et al., 2005], Aeolian Islands, Morgantina, and Ustica Island [Santi and Renzulli, 2006; Santi et al., 2013, 2015, 2020]. Concerning the basaltic millstones found in shipwreaks most of them come from Pantelleria, such as the hopper-rubber ones discovered at El Sec (Maiorca) dating to the 4th century BC [Williams-Thorpe and Thorpe, 1990] and the flat Archaic querns from the Phoenician cargo in Xlendi Bay (Gozo, Maltese Islands) dated to the 7th century BC [Renzulli et al., 2019]. In addition, hopper-rubber millstones made of the same basaltic lavas from Pantelleria, were also discovered in the Archaic levels (7th and 6th century BC) of the Phoenician colony of Gadir (i.e., Cádiz, Spain) in the Atlantic Ocean [Renzulli et al., 2019]. This confirms the widespread maritime network from east to west, just crossing the Strait of Gibraltar.

According to the huge references cited above dealing with basaltic millstones, similar macroscopic features, petrographic and textural characters can be observed: dark-grey to black, moderately to highly-vesciculated lavas with phenocrysts of plagioclase, clinopyroxene and olivine with a microcrystalline groundmass. Some samples could also contain orthopyroxenes and acicular prismatic ilmenite (Tholeiitic-Transitional series), whereas equidimensional Ti-magnetite is ubiquitous. In particular, it is well established that they may belong to basaltic lavas of the Na-Alkaline (Etna and Pantelleria) and the Tholeiitic/Transitional (Hyblaean Mountains) magma series [Williams-Thorpe 1988; Gluhak and Schwall, 2015; Renzulli et al., 2019; Santi et al., 2020]. Williams-Thorpe [1988] was among the first to emphasize the difficulty to determine provenance of basaltic millstones made all of "grey vescicular rocks, very similar in macroscopic features” coming from some Roman archaeological sites in Tunisia (Utica, Carthage, El Maklouba, Thuburbo Maius and Kelibia).

When dealing with basaltic millstones, the geochemical comparisons should be made with both the Italian basaltic sources of Eastern Sicily and Sicilian Channel and basaltic rocks (mostly OIB) that are present in the historic Levant region (Middle East). In fact, OIB source of Syria, Lebanon, Jordan and Israel represent an ancient lithic industry area for the manufacture of millstones including outcrops in the Lake Tiberias, the Golan Heights, the Jordan Plateau and Northern Syria [Xenophontos et al., 1988; Williams-Thorpe et al., 1991; Williams-Thorpe and Thorpe, 1993]. In this way literature data from the whole Levant region [Williams-Thorpe and Thorpe 1990, and reference therein], and from Lebanon [Stein and Hofmann 1992; Abdel-Rahman 2002; Abdel-Rahman and Nassar 2004], Syria [Mahfound and Beck, 1993; Demir et al. 2007; Lease and Abdel-Rahman 2008] and Jordan [Ibrahim Khalil et al., 2003; Ibrahim Khalil and Al-Malabeh, 2006] should be also taken into account when comparing geochemical data, mainly when dealing with the millstones of the Archaic period as the Phoenicians just originated from the Levant (the present Lebanon).

A rigorous approach on the basis of igneous petrology is necessary when comparing basaltic millstone with potential source areas. The TAS classification diagram [Kuno, 1968; Irvine and Barager, 1971; Le Bas et al., 1986] coupled with incompatible trace elements (HFSEs and LILEs) and rare earth elements (REEs) normalized to primordial mantle and chondrite respectively [Sun and McDonough, 1989] help to discriminate among the lavas of the two OIB magma series (Na-alkaline and Tholeiitic-Transitional) of Eastern Sicily and Sicilian Channel. In fact, the basaltic lavas of both the Na-Alkaline (Etna and Pantelleria) and the Tholeiitic/Transitional (Hyblaean Mountains) magma series show similar sub-parallel patterns, typical of intraplate-anorogenic OIB [Rollinson, 1993] the former showing enrichment in HFSEs and LILEs and a more fractionated REE pattern (i.e., higher LREEs/HREES and MREEs/HREEs ratios). Nevertheless, it is often insufficient to rely on trace elements patterns of basaltic millstones as it is not always possible to discriminate among OIB volcanoes and therefore using geochemical parameters such as binary major-trace elements or trace element ratios represent the most appropriate and robust assessment to match millstones with one of the Sicilian OIB source area [Santi et al., 2020 and reference therein]. Among the available literature database of volcanic rocks from Sicily [Peccerillo, 2005] lavas with $\mathrm{SiO}_{2}>57 \mathrm{wt} \%$, as well as those of the strongly silicaundersaturated (i.e., nephelinites and basanites) of the highly Na-Alkaline series of the Hyblaean Mountains can be excluded as they are geochemically (TAS) inconsistent with the basaltic millstones found in the Mediterranean area. The selected geochemical data therefore comprise Etna hawaiites and mugearites, basalts of the Tholeiitic/Transitional series of the Hyblaean Mountains and Na-alkaline basalts from the Pantelleria Island.

As already demonstrated in some of the most recent literature data on basaltic millstones [Santi et al., 2013, 2015, 2020; Renzulli et al., 2019], Etna lavas (hawaiites and mugearites), Tholeiitic/Transitional basalts of Hyblaean 


\section{Patrizia Santi et al.}

Mountains and Na-alkaline basalts from Pantelleria Island can be distinguished very well in the proposed discriminating binary diagram $\mathrm{La} / \mathrm{Yb} v s \mathrm{Sm} / \mathrm{Yb}$ (Figure $5 \mathrm{a}$ ). This diagram may represent a quick assessment tool for several basaltic millstones with OIB signature found in the Mediterranean areas. In addition, $\mathrm{Nb} v s \mathrm{TiO}_{2}$ diagram (Figure 5b) is also strongly suggested [Renzulli et al. 2019] to distinguish (and matching) basaltic millstones coming from the Hyblaean Mountains from those of the Pantelleria Island. It is worth to note that the high $\mathrm{TiO}_{2}$ content (2.4-4.0 wt\%) defines a chemical signature for the basaltic lavas of Pantelleria Island that allows us to rule out Etna and Hyblaean Mountains raw materials, which are all characterized by a $\mathrm{TiO}_{2}$ content $\leqslant 2.1 \mathrm{wt} \%$ [Peccerillo, 2005].
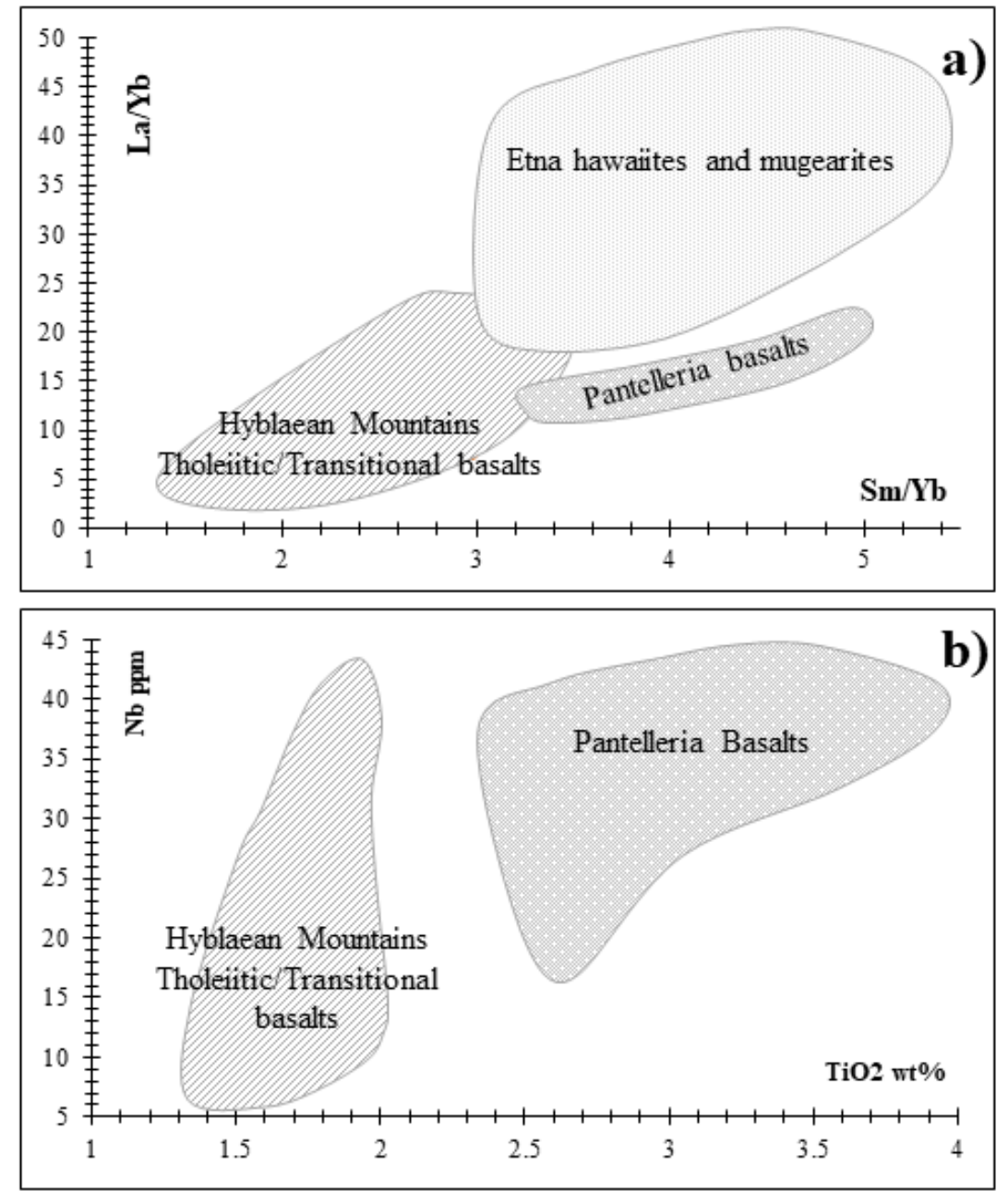

Figure 5. a) $\mathrm{La} / \mathrm{Yb}$ vs Sm/Yb diagram of selected basaltic lavas from Etna, Hyblaean Mountains and Pantelleria Island; b) $\mathrm{Nb} v s \mathrm{TiO}_{2}$ diagram of selected basalts from Hyblaean Mountains and Pantelleria Island (data from Peccerillo [2005]). $\mathrm{TiO}_{2}$ values are not water free basis.

\section{Discussion and final remarks}

The interest in studying the provenance of volcanic millstones is mainly linked to the pan-Mediterranean distribution of these artefacts through time. The ability to link provenance areas/production centres is of paramount importance to better understand the circulation of volcanic raw materials and artefacts in antiquity. In this way volcanologists and petrologists may strongly contribute to historical and archaeological studies. The scientific approach to obtain matching of millstones to the exploited volcanic deposits consist of using the 
fundamental methodology of igneous petrology: (i) thin section mineralogy and petrography and (ii) major-trace elements data comparisons. As a quick assessment tool to evaluate the most exploited four volcanic areas of Italy matching millstones, (“Orvieto quarries”, Etna, Hyblaean Mountains and Pantelleria Island) we propose a set of discriminating geochemical parameters (major-trace elements and element ratios diagrams). Most of the compositional literature studies deal with lava millstones from subaerial archaeological sites which may be only considered as "final destinations" for millstones trade. Increasing compositional data on the lava millstones from samples recovered in shipwrecked cargoes should therefore help to better define the sea-routes chosen in antiquity, from the exploited deposit to these "final destinations". The inclusion of shipwreck cargoes in the millstone archaeometric studies is therefore essential because it contributes to a better understanding of interactions between regions and cultures. Maritime millstone trade throughout the Mediterranean was particularly intensive in the Roman period, correlated to the collection of tithe taxes that involved the colonies of Sardinia, Sicily, North Africa and Spain. Millestones, often well-preserved in subaqueous environment are really witnesses of the shipwrecks, as recently discovered off Capo Rasocolmo (Messina, North-Eastern Sicily; Figure 6) at a depth of 115 meters together with rock ballast pile and lead ingots, dated to the 1st century AD.

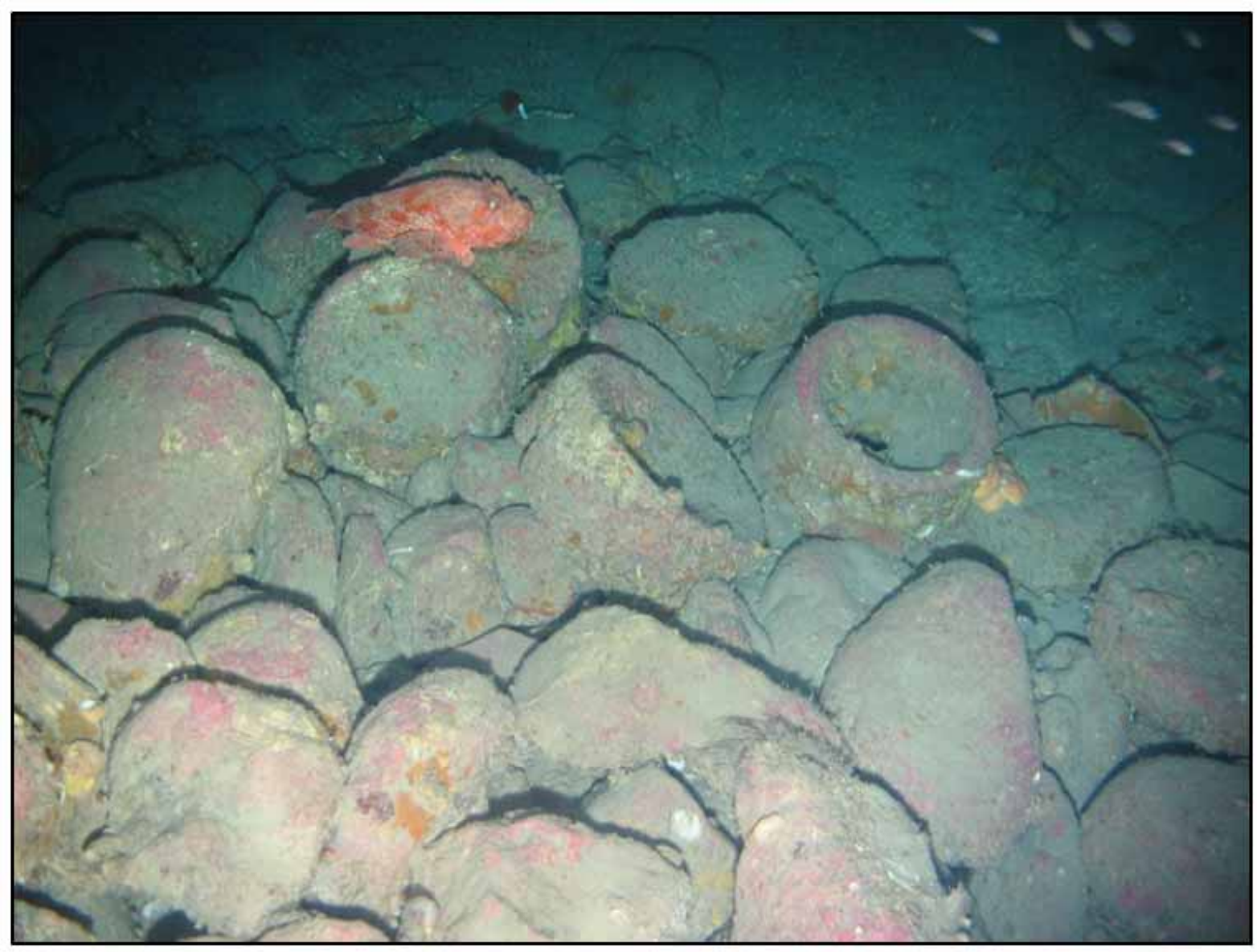

Figure 6. Image of the shipwreck cargo discovered in 2011 off Capo Rasocolmo at 115 meters of depth (Messina, NorthEastern Sicily) with several rotary millstones (metae and catilli; see the orange-red fish in the background as a scale). Photo by T. Gambin, kindly granted by the University of Malta and Soprintendenza del Mare, Sicily.

A comprehensive millstone trade network from the Archaic to the Roman age, by inland waterways and sea routes extending across the entire Mediterranean, is outlined in Figure 7, based on the available literature data (Santi, 2020 and reference therein). The leucite phonolite lava of the "Orvieto quarries" represents the lithotype 


\section{Patrizia Santi et al.}

with the largest diffusion, as millstones, at the scale of the whole Central-Western Mediterranean and Northern Italy. This statement is especially true for the time interval from 4th-3rd centuries BC up to the 2nd-3rd century $\mathrm{AD}$ (Figure 7a). Furthermore, the millstones found in the archaeological site of the Greek colony of Monte Castellazzo di Poggioreale [Ferla et al. 1984] and in the Phoenician site of the Rocca di Entella (Western Sicily) [Daniele, 1997] are both made by working the leucite phonolite lava from the "Orvieto quarries". These recoverings support the existence of commercial exchanges between the Etruscan and Greek populations. Between the 3rd century BC and the early Imperial Roman age, the basaltic millstones from the main volcanic areas of Sicily (hawaiites and mugearites from Etna and the Tholeiitic/Transitional basalts from the Hyblaean Mountains) are distributed across a local commercial network covering the island itself but also including the Central Mediterranean and the Ionian and Adriatic coasts (Figures 7b, c). Production centres located on the islands, such as that of Pantelleria, enjoyed a strategic position in areas constituting an almost obligatory stop during the crossing of the Mediterranean [Renzulli et al. 2019]. The important role played by the Pantelleria Island as an area of origin of basaltic millstones in the early Phoenician period (7th century BC) is confirmed by the finds from the archaeological site of Cadiz (Spain) and the shipwreck off the island of Gozo (Malta). This testifies that there was some form of connectivity that stretched across networks covering $1500 \mathrm{~km}$ - specifically, from the Pantelleria Island to the westernmost Phoenician colony, beyond the Straits of Gibraltar (Figure 7d).

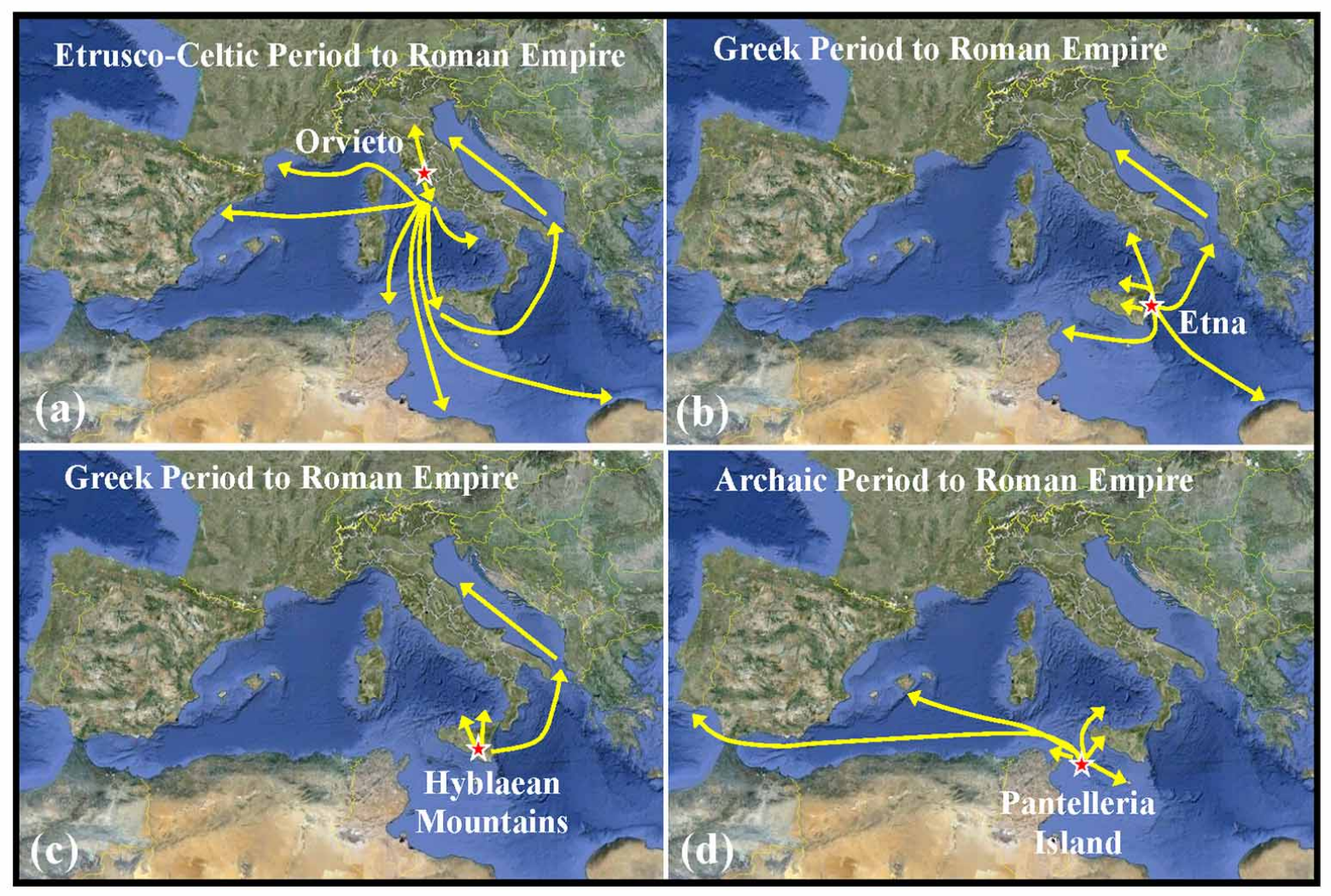

Figure 7. The millstone trade in antiquity in the Central-Western Mediterranean from the four most exploited Italian volcanic areas: a) “Orvieto quarries”; b) Etna; c) Hyblaean Mountains; d) Pantelleria Island [from Santi 2020, modified].

The strategic location of this island permitted a continuous production and trading of artifacts in subsequent centuries. Millstone from Pantelleria found in the shipwreck cargo (4th century BC) off the island of Mallorca (El Sec, Spain) as well as recovered in Carthaginian archaeological sites (Sicily and Tunisia) and from the Roman period (Sicily) [Williams-Thorpe, 1988; Williams-Thorpe and Thorpe, 1990] furtherly support the role of this 
island in maritime trade. It is important to note that during the Roman Period the four most exploited volcanic areas and production centres of lava millstones in the Latium-Umbria border, Eastern Sicily and Sicilian Channel were contemporaneously exploited. Nevertheless, only those located near Orvieto provided lava millstones (i.e. leucite phonolite, Vulsini Volcanic District) which spread throughout the Mediterranean. Outlining the lava millstone trade in the Mediterranean through time is also beneficial to the study of the technological evolution of grinding tools, which help to produce food that is part and parcel of Mediterranean culture.

Acknowledgements. This work was finacially supported by the University of Urbino Carlo Bo (Dipartimento di Scienze Pure e Applicate - DISPEA), research funding project-2017 entilted "Lo studio di reperti archeologici lapidei di natura vulcanica: un potente strumento di confronto reciproco per ricerche in campo vulcanologico e archeometrico” (Responsible P.Santi). Monica Piochi and two anonymous reviewers are acknowledged for their useful comments and suggestions.

\section{References}

Abdel-Rahman, A.F.M. (2002). Mesozoic volcanism in the middle est: geochemical, isotopic and petrogenetic evolution of extension-related alkali basalts from central Lebanon, Geol. Mag. 139, 621-640. https://doi.org/10.1017/S0016756802006829.

Abdel-Rahman, A.F.M. and P.E. Nassar (2004). Cenozoic volcanism in the middle east: petrogenesis of alkali basalts from northern Lebanon, Geol. Mag. 141, 545-563. https://doi.org/10.1017/S0016756804009604.

Alonso N. and R. Frankel (2017). A survey of ancient grain milling systems in the Mediterranean. Revue Archèologique de l'Est, 43ํ Suppl., 461-478.

Antonelli, F., G. Nappi and L. Lazzarini (2001). Roman millstones from Orvieto (Italy): petrographic and geochimical data for a new archaeometric contribution, Archaeom., 43, 2,167-189.

Antonelli, F., F. Bernardini, S. Capedri, L. Lazzarini and E. Montagnari Kokelj (2004). Archaeometric study of protohistoric grinding tools of volcanic rocks found in the Karst (Italy-Slovenia) and Istria (Croatia), Archaeom., 46, 4, 537-552.

Antonelli, F., L. Lazzarini and M. Luni (2005). Preliminary study on the import of lavic millstones in Tripolitania and Cyrenaica (Libya), J. Cul. Herit., 6, 137-145.

Antonelli, F. and L. Lazzarini (2010). Mediterranean trade of the most widespread Roman volcanic millstones from Italy and petrochemical markers of their raw materials, J. of Archaeol. Sci., 37, 2081-2092.

Antonelli, F., S. Columbu, M. de Vos Raaijmakers and M. Andreoli (2014). An archaeometric contribution to the study of ancient millstones from the Mulargia area (Sardinia, Italy) through new analytical data on volcanic raw material and archaeological items from Hellenistic and Roman North Africa, J. Archaeol. Sci., 50, 243261.

Bell, M. (2011). Agrarian policy, bucolic poetry, and figurative art in early Hellenistic Sicily, in: Krise und wandel. Süditalien und Sizilien in 4 und 3. Jahrhundert v. Chr., Internationaler Kongress anlässlich des 65, Geburtstages von D.Mertens, Wiesbaden, 193-211.

Bruschetti, P. (2004). Il porto di Pagliano tra Tevere e Paglia, in The Tiber Valley in Antiquity, Rome, 27-28 Abstract volume.

Buffone, L., S. Lorenzoni, M. Pallara and E. Zanettin (1999). Le macine rotatorie in rocce vulcaniche di Pompei, Riv. Studi Pompeiani, 10, 117-130.

Buffone, L., S. Lorenzoni, M. Pallara and E. Zanettin (2003). The millstones of Ancient Pompei: a petro-archaeometric study, Eur. J. Miner., 15, 207-215.

Cato, M.P. (160 BC). De Agri Cultura, X, 1-4.

Chartrain, A. (2015). Il mulino, una macchina dell'antichità, in: La civiltà del pane, G. Archetti (Ed.), Atti del Convegno Internazionale di Brescia, MilanExpo, suppl. Brixia, 433-468.

Childe, V.G. (1943). Rotary querns on the continent and in the Mediterranean basin, Antiquity,17, 19-26.

Curtis, R.I. (2001). Ancient food technology, Brill (Ed.), Boston, 510.

Daniele, D. (1997). Studio chimico-petrografico e individuazione delle aree di provenienza del materiale lavico delle macine di Entella, in: Atti delle II Giornate Internazionali di Studi sull'Area Elima, Gibellina, Pisa, 465-527. 


\section{Patrizia Santi et al.}

Demir, T., R.W.C. Westaway, D. Bridgland, M.S. Pringle, S. Yurtmen, A. Beck and G. Rowbotham (2007). Ar-Ar dating of Late Cenozoic basaltic volcanism in the northern Syria: implications for the history of incision by the river Euphrates and uplift of the northern Arabian platform, Tectonics, 26, https://doi.org/10.1029/2006TC001959.

Di Bella, M., P. Mazzoleni, S. Russo, S. Sabatino, G. Tigano and A. Tripodo (2016). Archaeometric characterization of Roman volcanic millstones from Messina territory (Sicily, Italy), Periodico di Mineralogia, 85, 69-81.

Di Bella, M., F. Italiano, M.C. Martinelli, P. Mazzoleni, S. Quartieri, G. Tigano, A. Tripodo and G. Sabatino (2018). Archeometric characterization of prehistoric grindstones from Milazzo Bronze Age settlement (Sicily, Italy), Archaeol. Anthropol. Sci., 10, 1571-1583.

Elliott, C., C. Xenophontos and J.G. Malpas (1986). Petrographic and mineral analyses used in tracing the provenance of Late Bronze Age and Roman artefacts from Cyprus, Rep. Deptm. Antiqu. Cyprus, 80-96.

Ferla, R., G. Alaimo, F. Falsone and F. Spatafora (1984). Studio petrografico delle macine di età arcaica e classica da Monte Castellazzo di Poggioreale, Sicilia Archaeologica, 56, 25-52.

Frankel, R. (2003). The Olynthus Mill, its origin and diffusion: typology and distribution, Am. J. Archaeol.,107, 1-21.

Gluhak, T.M. and C. Schwall (2015). Provenance analyses of the volcanic rock grinding stones from the Greek colony of Selinunte, Sicily (Italy) - constraints and possibilities, Archaeom., 57, 246-268, https://doi.org/10.1111/arcm.12086.

Griffiths, D.R. (2000). Uses of volcanic products in antiquity, London, Geol. Soc. Special Publication, 171, 15-23.

Hockensmith, C.D. (2009). The millstone industry: a summary of research on quarries and producers in the United States, Europe and elsewhere. McFarland \& Company, Inc., Publishers, Jefferson, North Carolina, and London, 269.

Holodňák, P. (2001). Experiments mletìm obilnin na žernovech tzv. Řeckého typu. Experiment mit dem Mahlen des Getreides an den Mahlsteinen des sog. Griechischen Typs (Balkenhandműhlen), Ach. Rozhledy, 53, 31-44.

Ibrahim Khalil, M. and I. Tarawneh, Kalid, Rabba (2003). Phases of activity and geochemistry of basaltic dike systems in northeast Jordan parallel to the Red Sea, J. Asian Earth Sci. 21, 467-472, https://doi.org/10.1016/S13679120(02)00075-5.

Ibrahim Khalil, M. and A. Al-Malabeh (2006). Geochemistry and volcanic features of Harrat el Fahda: a young volcanic field in northwest Arabia, J. Asian Earth Sci. 27,147-154, https://doi.org/10.1016/j.jeseas.2005.01.009.

Irvine, T.N., Baragar, W.R.A. (1971). A guide to chemical classification of the common volcanic rocks, Can. J. Earth Sci. 8, 523-548.

Junkelmann, M. (1997). Panis militaris, Mainz.

Kuno, H. (1968). Differentiation of basalt magma. In: Hess, H., Poldervaart, A. (Eds.), Basalts: The Poldervaart Treatise on Rocks of Basaltic Compositions, II, Wiley \& Sons, New York, 623-688.

Lease, N.A. and A.F.M. Abdel-Rahman (2008). The Euphrates volcanic field, northerneastern Syria: petrogenesis of Cenozoic basanites and alkali basalts, Geol. Mag., 145, 685-701, https://doi.org/10.1017/S0016756808004901.

Le Bas, M.J.; R.W. Le Maitre, A., Streckeisen; B. Zanettin (1986). A chemical classification of volcanic rocks based on the total alkali-silica diagram, J. Petrol., 27, 745-750.

Lorenzoni, S., M. Pallara, D. Vanturo and E. Zanettin (1996). Archaeometric preliminary study of volcanic millstones from Neolithic-Roman archaeological sites of the Altamura area (Apulia, Southern Italy), Sci. Technol. Cult. Herit., 5, 47-55.

Lorenzoni, S., M. Pallara and E. Zanettin (2000). Volcanic rock Bronze Age millstones of Apulia, Southern Italy: Lithology and Provenance, Eur. J. Mineral., 12, 877-882.

Lustrino, M., and M. Wilson (2007). The circum-Mediterranean anorogenic Cenozoic igneous province, Earth Sci. Rev., 81, 1-65.

Mahfound, R.F. and J.N. Beck (1993). Petrographic study of, and trace element distribution in, high-MgO, transitional, and high-Al2O3basalts from the coastal region and SW central Syria: a comparative study with similar basalts from the Aleutian Island Arc, J. Geodyn. 17, 57-76, https://doi.org/10.1016/0264-3707(93)90017-Z.

Mayesche, B. (1988). A Pompeian bakery on the via dell'Abbondanza, in: Studia Pompeiana and Classica in honour of Wilhelmina Jashemski, R.I. Curtis (Ed.), 1 A.D. Caratzas, New Rochelle, NY,149-166.

McCallum, M. (2010). The supply of stone to the city of Rome: a case study of the transport of anician building stone and millstone from the Santa Trinità quarry (Orvieto), in: Trade and Exchange, C.D. Dillan, C.L. White (Eds.) Springer Berlin, 5 .

Morelli, C. (1957). Gli avanzi Romani di Pagliano presso Orvieto, Boll. Ist. Artistico Orvietano, 13, 3-60. 
Moritz, L.A. (1958). Grain-mills and flour in classical antiquity, Oxford: Clarendon Press, 230.

Nappi, G., A. Renzulli, P. Santi and P.Y. Gillot (1995). Geological evolution and geochronology of the Vulsini Volcanic District (Central Italy), Boll. Soc. Geol., 114, 599-613.

Oliva, P., D. Beziat, C. Domergue, C. Jarrier, F. Martin, B. Pieraggi and F. Tollon (1999). Geological source and use of rotary millstones from the Roman iron-making of Les Martys (Montagne Noire, France), Eur. J. Mineral., 11, 757-762.

Parker, A.J. (1992). Cargoes, containers and stowage: the ancient Mediterranean, Int. J. Naut. Archaeol., 21, (1), 89-100. Peacock, D.S.P. (1980). The Roman millstone trade: a petrological sketch, World Archaeol., 12, 1, 43-53.

Peacock, D.S.P. (1986). The production of Roman millstones near Orvieto, Umbria, Italy, Antiquity J., 66, 45-51.

Peacock, D.S.P. (1989). The mills of Pompeii, Antiquity, 63, 205-214.

Peccerillo, A. (2005). Plio-quaternary volcanism in Italy, Springer Verlag, 365.

Pliny the Elder, 77-78 AD; Naturalis Historia, XXXVI, 135.

Py, M. (1992). Meules d'époque protohistorique et romaine provenant de Lattes, Lattara, 5, 183-232.

Renzulli, A., P. Santi, G. Nappi, M. Luni and D. Vitali (2002). Provenance and trade of volcanic rock millstones from Etruscan-Celtic and Roman archaeological sites in Central Italy, Eur. J. Mineral., 14, 175-183.

Renzulli, A. and P. Santi (2005). Petroarcheometria delle macine manuali, in: La Villa Romana di Cannetolo di Fontanellato, Ministero per i Beni e le Attività Culturali, Soprintendenza per i Beni Archeologici dell'EmiliaRomagna, 34-35.

Renzulli, A., P. Santi, T. Gambin and P. Bueno Serrano (2019). Pantelleria Island as a center of production for the Archaic Phoenician trade in basaltic millstones: new evidence recovered and sampled from a shipwreck off Gozo (Malta) and a terrestrial site at Cadiz (Spain), J. Archaeol. Sci.: Repo, 24, 338-349.

Rollinson, H. R. (1993). Using Geochemical Data: Evaluation, Presentation, Interpretation, Longman Geochemistry Series, 1993, 352.

Rostovtzeff, M. (1937). Two Homeric Bowls in the Louvre, Am. J. Archaeol., 41, 1, 86-96.

Santi, P., F. Antonelli, A. Renzulli and P. Pensabene (2004). Leucite phonolite millstones from the Orvieto production centre: new data and insights into the Roman trade, Per. Mineral., Special Issue, $32^{\circ}$ IGC, 73, 57-69.

Santi P. and A. Renzulli (2006). Italian volcanoes as landmarks for the spreading of trade networks during the Etruscan and Roman periods: the millstones and flagstones case study. Acta Vulc., 18 (1-2), 133-140.

Santi, P., A. Renzulli and R. Gullo (2013). Archaeometric study of the hopper-rubber and rotary Morgantina-type volcanic millstones of the Greek and Roman periods found in the Aeolian archipelago (southern Italy), Eur. J. Mineral., 25, 39-52.

Santi, P., A. Renzulli and M. Bell (2015). The volcanic millstones from the archaeological site of Morgantina (Sicily): provenance and evolution of the milling techniques in the Mediterranean area, Archaeom., 57, 5, 803-821.

Santi, P., F. Foresta Martin, F. Spatafora, S. De Vita and A. Renzulli (2020). Volcanic Grinding Tools in Ustica Island (Tyrrhenian Sea, Italy): Local Production vs. Import of Morgantina-Type Millstones in the Hellenistic-Roman Period, Minerals, 10, 389, http://doi:10.3390/min10050389.

Santi P. (2020). Evoluzione tecnologica e provenienza di macine frumentarie in pietra lavica: dall'età Fenicio-Punica all'Impero Romano. Studi Urbinati, Anno LXXXVII- 2020 Nuova Serie A-N.71, 1,2, 197-214.

Sjöqvist, E. (1960). Excavations at Morgantina (Serra Orlando) 1959. Preliminary Report IV, Am. J. Archaeol., 64, 2, 125-135.

Stein, M. and A.W. Hofmann (1992). Fossil plume head beneath the Arabian lithosphere? Earth Planet. Sci. Lett. 114, 193-209, https://doi.org/10.1016/0012-821X(92)90161-N.

Sun, S.S. and W.F. McDonough (1989). Chemical and isotopic systematics of oceanic basalts: implications for mantle composition and processes. In: Saunders, A.D., Norry, M.J. (Eds.), Magmatism in Ocean Basins, Geol. Soc. London, Special Publication, 42, 313-345.

Washington, H.S. (1896) - Italian petrological sketches, I. The Bolsena Region. J. Geol., 4, 541-566.

Wefers, S. (2011). Still using your saddle quern? A compilation of the oldest known rotary querns in western Europe, in: Bread for the People: the archaeology of mills and milling, D. Williams, D. Peacock (Eds.), Archaeopress, University of Southampton, Series in Archaeology, 3, 67-76.

Williams, D. and D. Peacock (Eds.) (2011). Bread for the People: the archaeology of mills and milling, Archaeopress, University of Southampton, Series in Archaeology, 380.

White, D. (1963). A survey of millstones from Morgantina, Am. J. Archaeol., 67, 2, 199-206. 


\section{Patrizia Santi et al.}

Williams-Thorpe, O. (1988). Provenancing and Archaeology of Roman Millstones from the Mediterranean Area, Rock Mechanics, 15, 1-7.

Williams-Thorpe, O. and R.S. Thorpe (1988). The provenance of Donkey mills from Roman Britain, Archaeom., 30, 275-289.

Williams-Thorpe, O. and R.S. Thorpe (1990). Millstones procenancing used in tracing the route of a fourth-century B.C. Greek merchant ship, Archaeom., 32, 115-137.

Williams-Thorpe, O. and R.S. Thorpe (1991). Millstones that mapped the Mediterranean, New Scientist, 42-45.

Williams-Thorpe, O. and R.S. Thorpe (1993). Geochemistry and trade of Eastern Mediterranean millstones from the Neolithic to Roman Periods, J. Archaeol. Sci., 20, 263-320.

Winter, J.D. (2010). Principles of Igneous and Metamorphic Petrology, 2nd Edition, Whitman College,

Xenophontos, C., C. Elliot and J.G. Malpas (1988). Major and trace-element geochemistry used in tracing the provenance of late Bronze Age and Roman basalts artefacts from Cyprus, Levant 20, 169-183. 